Approximately 10 per cent of our scientific and technical staff are allotted to 'systems engineering'. Its staff members must supply a proper blending of competence and background in each of the three areas with which it makes contact: research and fundamental development, specific systems and facilities development, and operations. It is therefore largely made up of men drawn from these areas who have exhibited unusual talents in analysis and the objectivity so essential to their appraisal responsibility.

We shall now turn to specific systems and facilities development, the third area of creative technology. The work here is programmed according to the patterns that systems engineering studies prescribe.

The work of this area determines the design of new systems and facilities for the operating companies. The motif of its programmes is the realization of a design that will furnish service of the prescribed quality at the lowest complete cost. The important elements of the complete cost are operation and maintenance expense and the capital charges that cover the annual costs of the investment in the new systems and facilities. The work is therefore directed at minimum cost with the best economic balance between these elements of cost. To determine the design for manufacture that will provide this cost balance, the engineers of this area work in most intimate contact with the engineers of manufacture of the Western Electric Company, the manufacturing subsidiary of the Bell System, and our systems engineering area which interprets the service requirements and the operation and maintenance cost factors.

While the work of this area is all done within the limits of the new knowledge in our reservoir and of established development and design practices, it is, even so, a most complex operation of technology, which involves close interweaving of the developerdesign function, the manufacturing function, and the telephone service function. Intimate team-work between the groups involved is of paramount import. ance. The end products are complete specifications and designs for manufacture and instructions for operation and maintenance.

Some 60 per cent of the members of our professional staff work in this area. They are principally graduate engineers - electrical, mechanical, chemical and metallurgical-from our technical schools and universities.

The story of Bell Telephone Laboratories would not be complete without reference to its military development programmes for the United States. During the War we turned our attention almost completely to the creative technology of instrumenta. tion for warfare. New facilities for communications, radar, sonar, gun directors, are typical of our areas of work.

At the close of hostilities, with military preparedness becoming an important element of national policy, our Laboratories has continued in military creative technology. Approximately 20 per cent of our effort is so employed.

The philosophy of work and organisation of effort ovolved in our serving an operating organisationthe Bell System-makes us uniquely suited to aid the Services, which is another operating organisation. The pattern of our activities for the Bell System-a broad programme of research and fundamental development to obtain new knowledge of value to telephone service ; the scientific determination of the best applications of the new knowledge in the interest of service ; and the development and design of new facilities best suited to the service-is the pattern in which we are carrying out our work in creative technology for the military.

By the mid-1930's we were painfully aware of the limitations on our effectiveness imposed by the nonfunctional housing of our Laboratories in New York City. A small committee made a study of housing, services and facilities, extending over three or four years, arriving at a completely new design of labor. atory buildings, service arrangements and facilities that made a distinct break with the past.

The motif of the design was the maximum of functional facility with complete flexibility in room size, laboratory services and equipments. Size of rooms, their equipments and services employed cen be quickly and inexpensively altered. The original unit was completed in 1941 at Murray Hill, New Jersey, some twenty miles from New York City; and was first employed in our war research and development programmes.

The effectiveness which this functional structure added to our war research and development programmes completely justified the philosophy of design. Construction on a second unit was begun immediately after the close of hostilities. We are now completing its occupancy and will have some 2,500 scientific men, engineers and their associates (40 per cent of our staff) working in these new laboratorios.

The design of the Murray Hill Laboratories has attracted international attention. Some thirty-two laboratories in the United States have been constructed since the close of the War along the functional lines established by our design. We have visitors from many parts of the world studying the design pattern. While I do not know the extent to which it has been incorporated in new buildings in other countries, we know of one as far removed as India that has followed its basic principles.

\section{THOMAS WRIGHT'S “ORIGINAL THEORY" OF THE MILKY WAY}

A CELEBRATION in honour of Thomas Wright of Durham was held on June 2 in the Science Laboratories of the University of Durham. Different from most historical celebrations, its purpose was not to recall a memorable date in the life of a famous man but to direct the attention of wider circles to an astronomer much less known than he deserves to be. The "Encyclopedia Britannica" does not mention him at all, and paragraphs concerning him in biographical dictionaries are very meagre and inaccurate. Born in Byers Green, a little village near Durham City, he spent most of his life there and called himself always Thomas Wright "of Durham"; so two hundred years after the publication in 1750 of his most important book "An Original Theory or New Hypothesis of the Universe", in which he gives an explana. tion of the Milky Way, the University of Durham made this attempt to revive his memory.

The celebrations were introduced by Prof. $H$. Dingle, of University College, London. In a lecture on "Thomas Wright's Astronomical Heritage", he examined carefully all sources of information which might possibly have influenced Wright in his astronomical conceptions and especially in his interpretation 
of the Milky Way. He came to the conclusion that all Wright's forerunners had considered the Milky Way as one of the constellations on the celestial sphere; that since Galileo this luminous band was known to consist of many stars, and that from one author-Dr. Derham, whom Wright mentions-he might have learnt that the strange appearance of the galaxy presented an unsolved problem; but the direction in which Wright found the explanation is not foreshadowed anywhere and his publication was in the fullest sense original.

Following the first speaker, Prof. F. A. Paneth, of the University of Durham, discussed the two reasons for which Thomas Wright ought to be remembered in the history of astronomy. He was the originator of the idea of the disk-shaped universe ; it occurred to him that if our sun with its planets were situsted in the interior of a flat stellar system, on purely geometrical grounds we would see many more stars when looking in the direotion of the plane of the disk than in any otber direction. In this case there would be in Nature no crowding together of stars in the Milky Way, but this celestial circle would only be an optical effect, due to the peculiar form of the stellar system to which we belong.

Essentially the same interpretation of the Milky Way was given thirty-five years later by W. Herschel, who-without any knowledge of 'Thomas Wright's book-based it on the convincing results of his stargauging in various directions of the sky. There can be no doubt that the priority of this fundamental idea belongs to Wright; but since his "Original Theory" had no direct influence on the development of modern astronomy, this historical fact alone would have not more than a limited interest for specialists. There is, however, a second, much stronger, argument for remembering. Wright: his book was the spark which fired the imagination of Immanuel Kant to develop his famous theory of celestial evolution. This great scientific cosmogony would probably never have been written if Kant had not seen, by mere chance, an abstract of Wright's book in a German periodical. Wright's conception of the universe was purely geometrical, but Kant considered immediately the forces acting therein; the disk-like shape of the stellar system seemed to him proof of its rotationa conclusion since verified-and the elliptical nebulæ he interpreted correctly as external galaxies. (Kant was the first to use the word in the plural !) The idea of cosmic evolution which is the essential part of Kant's theory follows almost logically from Wright's assumption of the flat universe.

After the two lectures, an excursion was made to a strong stone tower at Westerton, about seven miles from Durham, which for more than a century has been known to the local population as the "Westerton Folly", its original purpose being completely forgotten. Now it bears a freshly fixed tablet with the inscription :

This Observatory Tower was erected by THOMAS WRIGHT

born at Byers Green 1711, djed there 1786. To commemorate his treatise

THEORY OF THE UNIVERSE,

published 1750 , this tablet was placed here

by the University of Durham, 1950.

An exhibition in the University of Durham Library of Thomas Wright's published works, of manuscripts or photostat copies of manuscripts from the British Museum, the Royal Society, the Royal Astronomical
Society and the Newcastle Public Library, and of drawings and pencil sketches representing a great variety of subjects, gave visitors a good impression of the genius of this versatile and highly original man.

It is hoped that his autobiography, the manuscript of which is still extant, will be edited this year by a competent scholar; it tells a very human, and in parts touching, story of a boy whose early love for the study of mathematics and astronomy was so much opposed by his father that he ran away from home, penniless, but carrying with him the load of all those books which his father had not burned. It narrates how, against many odds, he slowly succeeded in having his works printed and getting access to the houses of the nobility as a teacher of astronomy, which in those days was a fashionable hobby with the ladies. It finishes with the description of the stately house he built in his native village and in which he died in 1786 , too isolated, it seems, to have heard before his end of Herschel's fundamental paper presented to the Royal Society a year earlier, which proved the correctness of Wright's idea about the nature of the Milky Way.

F. A. Paneth

\section{INTERNATIONAL COMMITTEE FOR BIRD PRESERVATION}

\section{EIGHTH INTERNATIONAL CONFERENCE}

$\mathrm{T}$ HE Eighth International Conference of the International Committee for Bird Preservation, the first world conference to be held since the Second World War, took place in Uppsala during June 8-10, and was attended by representatives of the following national sections: Austria, Belgium, Canada, Denmark, France, Germany, Great Britain, Greece, Hungary, Iceland, Italy, Japan, Netherlands, Spain, Sweden, Switzerland and the United States ; Luxembourg, which is not yet a member of the International Committee, sent an observer.

The following elections were made: President, Jean Delacour (United States); Vice-Presidents, Leon Lippens (Belgium) and Colonel Casales (Argentine) ; Secretaries, Miss Phyllis Barclay-Smith (Great Britain), Richard. Pough (United States) and Georges Olivier (France). Dr. Bøje Benzon (Denmark) was elected chaiman, and Prof. A. Ghigi (Italy) vicechairman, of the European Continental Section.

The business of the Conference opened by a report of the international sub-committee on conditions of birds transported by air, which set forth measures considered necessary to ensure the proper care of these birds in transit. Prof. Ghigi (Italy) directed attention to the harmful effects of delays due to customs formalities in dealing with birds being transported by air, and it was agreed at the meeting that the governments concerned should be approached, with the request that measures should be taken to enable customs officials to give priority to live birds. A full report of the administration and research being carried out by the recently formed International Wildfowl Research Institute at Tring, England, was submitted to the meeting on behalf of Dr. Edward Hindle, the honorary director, giving details of the work being carried out on the summer migration of the sheld-duck (see Nature, December 31, 1949, p. 1122), with special reference to food and food preferences, mortality, correlation of ringing re- 